University at Buffalo School of Law

Digital Commons @ University at Buffalo School of Law

$11-1-1978$

\title{
State Restrictions on Medicaid Coverage of Medically Necessary Services
}

Lucinda M. Finley

University at Buffalo School of Law

Follow this and additional works at: https://digitalcommons.law.buffalo.edu/journal_articles

Part of the Health Law and Policy Commons, and the Social Welfare Law Commons

\section{Recommended Citation}

Lucinda M. Finley, State Restrictions on Medicaid Coverage of Medically Necessary Services, 78 Colum. L. Rev. 1491 (1978).

Available at: https://digitalcommons.law.buffalo.edu/journal_articles/665

This article originally appeared at 78 Colum. L. Rev. 1491 (1978). Reprinted by permission.

\section{C) ${ }_{\text {COPYRIGHT }}^{\text {N }}$}

This Article is brought to you for free and open access by the Faculty Scholarship at Digital Commons @ University at Buffalo School of Law. It has been accepted for inclusion in Journal Articles by an authorized administrator of Digital Commons @ University at Buffalo School of Law. For more information, please contact lawscholar@buffalo.edu. 


\section{NOTE}

\section{STATE RESTRICTIONS ON MEDICAID COVERAGE OF MEDICALLY NEGESSARY SERVICES}

\section{INTRODUCTION}

The Medicaid program, title XIX of the Social Security Act, ${ }^{1}$ was enacted in 1965 to provide partial federal funding of the costs of medical services for the indigent." Medicaid is a program of "cooperative federalism" -it is administered by the states, subject to certain federal requirements, and its costs are shared by the federal and state governments. Each participating state ${ }^{3}$ must adopt a Medicaid plan ${ }^{4}$ detailing the services that will be funded. ${ }^{5}$ The statute requires that state plans cover five general categories of medical services, ${ }^{6}$ and permits coverage of several other categories, ${ }^{7}$ but does not specify any items or procedures that must be included within any of these service categories.

Dramatic, unanticipated cost increases and problems of fraud and abuse ${ }^{8}$

1. Social Security Amendments of 1965, Pub. L. No. 89-97, 79 Stat. 286 (codified in amended form at 42 U.S.C. $\$ 1396$ (1976)). All references will be to the codification.

2. The program was a response to widespread problems of poor quality and low availability of medical services for the indigent. S. REP. No. 404, 89th Cong., 1st Sess. 74-76, reprinted in [1965] U.S. CoDE CoNG. \& AD. News 1943, 2014-15 [hereinafter cited as 1965 S. REP.].

Title XIX consolidated and liberalized existing federal health care assistance programs scattered throughout the Social Security Act. Consequently, Congress anticipated that Medicaid would have a limited social impact, and would cost the federal government no more than an additional $\$ 200$ million in its first year of operation. Id. at 85 . See generally R.B. Stevens \& R. Stevens, Welfare Medicine in America 19-56 (1974).

3. All states except Arizona currently offer Medicaid assistance. For the scope of coverage in each state, see [1977] 2 Medicare \& MediCAID GuIDE (CCH) II 15,500-15,660.

4. 42 U.S.C.A. § $1396 \mathrm{a}(\mathrm{a})$ (1)-(40) (West 1974 \& Supp. 1978), sets forth the required components of a state Mèdicaid plan.

5. The plan must also specify the individuals who will be eligible for benefits. In this regard, the plan must provide

for making medical assistance available to all individuals receiving aid or assistance under any plan of the State approved under subchapter I [Old Age Assistance], X [Aid to the Blind], XIV [Aid to the Disabled], XVI [Supplemental Security Income], or part A of subchapter IV [Aid to Families with Dependent Children] of this chapter....

42 U.S.C. $\$ 1396 a(a)(10)(A)(1976)$, and may provide assistance to the "medically needy"those who do not qualify for public assistance yet cannot afford the costs of necessary medical care. 42 U.S.C. $\$ 1396 a(a)(10)(C)(1976)$.

6. 42 U.S.C. $\$ 1396 a(a)(13)(B)(1976)$. The mandatory coverage categories are set forth at 42 U.S.C. $\$ 1396 \mathrm{~d}(\mathrm{a})(1)-(5)$ : (1) inpatient hospital services; (2) outpatient hospital and rural health clinic services; (3) laboratory and x-ray services; (4) skilled nursing facility services, family planning services, and early and periodic screening and diagnostic service for individuals under 21; and (5) physicians' services.

7. At their option, states may include coverage for such service categories as: home health care; private duty nursing services; clinic services; dental services; prescription drugs and eyeglasses; rehabilitative services; physical therapy; and inpatient psychiatric services for individuals under 21. 42 U.S.C. $\$ 1396 \mathrm{~d}$ (a) (7)-(16) (1976).

8. See S. REP. No. 222, 91 st Cong., 1st Sess. 2, reprinted in [1969] U.S. Code Cong. \& AD. News 1077, 1078; H. R. ReP. No. 231, 92d Cong., 1st Sess. (1971), reprinted in [1972] U.S. Code Cong. \& Ad. News 4989. See generally R. B. Stevens \& R. Stevens, supra note 2. 
have led to state efforts to limit the scope of Medicaid coverage. ${ }^{9}$ These limitations include restrictions on the number of Medicaid-funded inpatient days, curtailment of the scope of different services within general categories, absolute exclusion of benefits for certain operations, and prohibitions on benefits for all abortions except those necessary to preserve a woman's life. ${ }^{10}$

Challenges to these state coverage restrictions have called into question the extent of a state's discretion to define and limit its Medicaid program. Specifically, it has been contended that states must provide benefits for all "medically necessary" care. ${ }^{11}$ Although the statute provides no direct guidance on this question, ${ }^{12}$ it may nonetheless implicitly require that certain items or procedures be covered in a state's plan. Such implicit requirements can only be ascertained through careful analysis of the Medicaid scheme.

This Note first will examine Medicaid's statutory scheme as it relates to state discretion to impose restrictions on Medicaid coverage. The concept of "medically necessary" will then be defined, and its relevance to the question of state discretion examined. Finally, this Note will turn to specific restrictions that have been imposed by different states and analyze their validity within the statutory scheme.

\section{The Statutory Framework}

A state Medicaid plan must conform to certain general federal requirements embodied in title XIX ${ }^{13}$ and the accompanying HEW regulations. ${ }^{14}$ Since title XIX does not specify which items or procedures a plan must include, any argument that a state is required to fund a particular type of care must be drawn from these general federal requirements.

The preamble to the Medicaid statute, section 1396, imposes no direct requirements on the states but is nonetheless highly relevant because it sets forth the general purpose of the statute. This section authorizes appropriations "[f]or the purpose of enabling each State, as far as practicable under the conditions in such State, to furnish ... medical assistance on behalf

9. Congress has also amended title XIX in order to impose limitations aimed at controlling the cost of Medicaid. See, e.g., Social Security Amendments of 1972 Pub. L. No. 92-603, tit. II, 86 Stat. 1329 (authorizing premium payments for the "medically needy," and cost-sharing by recipients for optional service categories); Social Security Amendments of 1967, Pub. L. No. $90-248,81$ Stat. 821 (placing an upper limit on the amount of income that can qualify an individual as "medically needy").

10. See notes 100-67 and accompanying text infra. For other examples of limitations imposed by state plans, see [1977] 2 MeDiCAID GUIDE (CCH) II 15,500-15,660.

11. Compare Rush v. Parham, 440 F. Supp. 383 (N.D. Ga. 1977), appeal filed sub nom. Rush v. Poythress No. 77-2743 (5th Cir. Apr. 1978), and Zbaraz v. Quern, [1978 Transfer Binder] Medicare \& Medicald Guide (CCH) I 29,001 (N.D. Ill. May 15, 1978) (title XIX requires states to fund all medically necessary services), with Preterm, Inc. v. Dukakis, No. 78-1324 (1st Cir. Jan. 15, 1979), and, Virginia Hosp. Ass'n. v. Kenley, 427 F. Supp. 781 (E.D. Va. 1977) (holding that states may exclude benefiits for some medically necessary care).

12. See notes 6-7 and accompanying text supra.

13. See note 4 supra.

14. HEW regulations are promulgated under the authority granted by 42 U.S.C. $\$ 1302$ (1976), and have the force of federal law upon the states. See King v. Smith, 392 U.S. 309, 317 (1968); Massachusetts Gen. Hosp. v. Sargent, 397 F. Supp. 1056, 1061 (D. Mass. 1975). 
of ... individuals, whose income and resources are insufficient to meet the costs of necessary medical services . . ." 15 While the preamble does not define the type of "medical assistance" for which appropriations are authorized, ${ }^{16}$ it does describe the intended beneficiaries as persons who cannot afford "necessary medical services." Since the statute was enacted to meet the medical needs of these persons, the purpose of the statute arguably would be defeated unless participating states were required to provide necessary medical care. ${ }^{17}$ Any requirement that all necessary services be funded, however, apparently need only be met to the extent "practicable under the conditions in [each] state."

Section 1396a (a) (17) of the statute authorizes each state to set its own standards for determining the extent of medical assistance offered under its Medicaid plan. ${ }^{18}$ This discretion to expand or restrict coverage within service categories, however, is limited by a requirement that standards must be "reasonable" and "consistent with the objectives" of title XIX.19 Because of this language, a plan's coverage-and thus any specific coverage limitations-must be reviewed for reasonableness. ${ }^{20}$

The HEW regulation implementing section $1396 \mathrm{a}$ (a) (17) ${ }^{21}$ further defines the limitation of reasonableness placed on a state's discretion to establish coverage standards. The amount, duration, and scope of services covered by the state plan must be sufficient "to reasonably achieve the purpose" of each item of medical care. Moreover, standards that arbitrarily restrict coverage solely because of the type of illness or condition are prohibited. The regulation also suggests that coverage restrictions based on the criterion of medical necessity would be appropriate.

Other elements of title XIX, while not specifically addressed to state discretion to set coverage standards, are also relevant to the question of what a state must include in its plan. Section $1396 \mathrm{a}(\mathrm{a})(19)$ requires states to provide safeguards so that care will be provided in a manner consistent with

15. 42 U.S.C. $\$ 1396$ (1976).

16. Id. $\S 1396 \mathrm{~d}(\mathrm{a})$ (1976) defines "medical assistance" in terms of general service categories, see notes 6-7 supra, but contains neither an enumeration of the items and procedures to be funded nor the phrase "necessary medical services." The Court of Appeals for the First Circuit was the first court to recognize the structural significance of this fact. See Preterm, Inc. v. Dukakis, No. 78-1324, slip op. at 6 (1st Cir. Jan. 15, 1979).

17. Cf. Roe v. Norton, 522 F.2d 928, 939-40 (2d Cir. 1975) (Mulligan, J., dissenting) ("necessary" implicitly modifies "medical assistance," indicating states may not fund elective procedures). See note 69 infra.

18. 42 U.S.C. $\$ 1396 \mathrm{a}(\mathrm{a})(17)$ (1976).

19. Id. This section provides, in part, that a state plan must "include reasonable standards ... for determining eligibility for and the extent of medical assistance under the plan which .... are consistent with the objectives of this subchapter. . .."

20. See Beal v. Doe, 432 U.S. 438, 444 (1977).

21. 42 C.F.R. $\$ 449.10$ (a)(5)(i) (1977), which provides that a state plan must: Specify the amount and/or duration of each item of medical and remedial care and services that will be provided. ... Such items must be sufficient in amount, duration and scope to reasonably achieve their purpose.... [T] deny or reduce the amount, duration, or scope of, such services ... solely because of the diagnosis, type of illness or condition. Appropriate limits may be placed on services based on such criteria as medical necessity or those contained in utilization or medical review procedures. 
the best interests of Medicaid recipients. ${ }^{22}$ This section arguably can be read to require states to cover all medically necessary care, because any restriction on the funding of such care would not be in the best interests of all individual Medicaid patients. ${ }^{23}$ States are also required under section 1396a (a) (30)-(31) of the statute to establish "utilization" review procedures to examine the necessity of items of medical care contained in claims for reimbursement. ${ }^{24}$ This requirement is intended to discourage improper or excessive use of health care services, ${ }^{25}$ and suggests that states may exclude coverage for unnecessary medical care. ${ }^{26}$

The statutory sections set forth above must be read in light of two major amendments to title XIX that have increased each state's control over the content of its plan. Section 1903 (e) of the original statute required states to broaden the scope of covered services so that all eligible individuals would receive comprehensive medical care by $1977 .{ }^{27}$ HEW defined comprehensive care to include all goods and services ordered by a physician within the scope of his practice..$^{28}$ During the late 1960's and early 1970's, however, medical care costs rose at an unprecedented rate, and the comprehensive coverage requirement of section 1903(e) threatened to impose a staggering financial burden on the states. ${ }^{29}$ Congress concluded that the

22. 42 U.S.C. $\$ 1396 a(a)(19)$ (1976), which provides that a state plan must "provide such safeguards as may be necessary to assure that eligibility for care and services under the plan will be determined, and such care and services will be provided, in a manner consistent with simplicity of administration and the best interests of the recipients."

23. This argument was implicitly accepted by the court in Rush v. Parham, 440 F. Supp. 383, 386, 388 (N.D. Ga. 1977), appeal filed sub nom. Rush v. Poythress, No. 77-2743 (5th Cir. Apr. 1978). See Plaintiffs' Brief in Support of Interim Relief at 13-14, Right to Choose v. Byrne, No. C-3817-77 (N. J. Super. Ct. Ch. Div. Jan. 10, 1979). But see Virginia Hosp. Ass'n v. Kenley, 427 F. Supp. 781 (E.D. Va. 1977). The argument, however, is seriously undercut by the legislative history. See note 79 and accompanying text infra.

24. 42 U.S.C. $\$ 1396 \mathrm{a}(\mathrm{a})(30)-(31)$ (1976). See also 42 U.S.C. $\$ \S 1320 \mathrm{c}-1$ to -19 (1976) (establishing Professional Standards Review Organizations), discussed in Gosfield, Medical Necessity in Medicare and Medicaid: The Implications of Professional Standards Review Organizations, 51 TEMP. L.Q. 229 (1978).

25. For Congress's original intentions in enacting utilization review, see generally S. REP. No. 1230, 92d Cong., 2d Sess. (1972); Gosfield, supra note 24.

26. Professor Gosfield argues that if a Professional Standards Review Organization (PSRO) determines that an item of care is "medically necessary," that item will automatically be funded-thus, states are required to fund all medically necessary services. Gosfield, supra note 24, at 270-80. The existence of PSROs does not resolve the question, however, because those bodies can only operate within the ambit of a state Medicaid plan. If the plan excludes abortions, for example, a PSRO would not be called upon to review the medical necessity of abortions, because they would not be funded under state law. The exclusion might nonetheless be invalid as inconsistent with the federal requirements imposed by title XIX.

27. Social Security Amendments of 1965, Pub. L. No. 89-97, §1903(e), 79 Stat. 286 (originally codified at 42 U.S.C. $\$ 1396$ b(e) (1970)) provided that:

The Secretary shall not make payments ... to any State unless the State makes a satisfactory showing that it is making efforts in the direction of broadening the scope of the care and services made available under the plan and in the direction of liberalizing the eligibility requirements for medical assistance, with a view toward furnishing by July 1, 1977, comprehensive care and services to substantially all individuals who meet the plan's eligibility standards with respect to income and resources . . . .

28. S. ReP. No. 222, supra note 8, at 4, reprinted in [1969] U.S. Code Cong. \& AD. News at 1081 .

29. Id. 
requirement was no longer practicable, ${ }^{30}$ and repealed section $1903(\mathrm{e})$ in $1972 . .^{31}$

The original Medicaid statute also contained section 1902(d), which prohibited a state from reducing the extent of care and services provided under its plan if the restriction would cause a reduction in the total state Medicaid expenditure from one year to the next. ${ }^{32}$ This maintenance of effort requirement inhibited states from making significant reductions in the scope and extent of their plans' coverage. ${ }^{33}$ Congress concluded that this restrictive effect of section 1902(d) could, in some instances, impose impracticable fiscal demands on the states. ${ }^{34}$ Thus, this section was also in $1972 .{ }^{35}$

Both of these amendments to title XIX reflect congressional concern for state fiscal interests, and both expanded state discretion to limit Medicaid coverage. The current statutory scheme gives states considerable freedom to define and restrict their Medicaid programs: the most specific limitation on this state discretion is the requirement that any restriction be reasonable and consistent with the program's objectives. This Note will next examine whether this limitation, in conjunction with the other relevant statutory elements, can be read to require states to fund all medically necessary services.

\section{Medical Necessity}

The debate over a state's ability to restrict coverage for medically necessary care has intensified since the 1977 Supreme Court decision in Beal v. Doe. ${ }^{36}$ Beal upheld a Pennsylvania regulation limiting Medicaid funding to medically necessary abortions ${ }^{37}$ as consistent with title XIX. The Court asserted that state discretion under the statute to adopt coverage standards ${ }^{38}$ included the ability to limit funding for purely elective treatment. Even within the mandatory service categories, therefore, states were not required to fund every procedure since some such procedures are elective. ${ }^{39}$ The only limit on this broad discretion, in the Court's view, was the requirement of section $1396 \mathrm{a}(\mathrm{a})(17)^{40}$ that standards be reasonable and

30. Id. (1972).

31. Social Security Amendments of 1972, Pub. L. No. 92-603, tit. II, §230, 86 Stat. 1329

32. Act of Aug. 9, 1969, Pub. L. No. 91-56, §2(d), 83 Stat. 99 (originally codified at 42 U.S.C. $\$ 1396 a$ (d) $(1970))$.

33. H.R. REP. No. 231, supra note 8, at 5086-87.

34. Id.

35. Social Security Amendments of 1972, Pub. L. No. 92-603, tit. II, § 231, 86 Stat. 1329.

36. 432 U.S. 438 (1977).

37. Abortions were defined as medically necessary if the health of the woman was threatened, if there was a probability of a deformed or mentally deficient fetus, or if the woman's mental or physical health would be threatened by the continuance of a pregnancy resulting from rape or incest. Id. at 441 n.3.

38. 42 U.S.C. $\$ 1396 a(a)(17)$ (1976). See notes 18-19 and accompanying text supra.

39. 432 U.S. at 444-45.

40. See notes 18-19 and accompanying text supra. 
consistent with the objectives of title XIX.41 Thus, if a state can offer a strong interest to justify a coverage restriction, the standard will be presumed reasonable. ${ }^{42}$ Pennsylvania's regulation, justified by the state's interest in encouraging normal childbirth, ${ }^{43}$ was held to meet this test.

\section{A. The Definition of "Medically Necessary"}

The Court did not define "medically necessary care" in Beal because the only issue raised in that case was the validity of a restriction on funding non-necessary care. Moreover, Congress did not define the statutory term "necessary medical services" ${ }^{44}$-neither title XIX itself nor the legislative history contains any definition. To determine whether the "medical necessity" of a given item or procedure restricts a state's freedom to limit funding for it, however, a definition of "medically necessary" that is appropriate in the funding context must be formulated.

1. Judicial Approaches. The definition most often advanced is the standard suggested by the Supreme Court in Doe v. Bolton. ${ }^{45}$ In one branch of the case, the Court considered whether a state statute proscribing all abortions except those determined by a physician, in his "best clinical judgment," to be "necessary" was void for vagueness. ${ }^{46}$ The Court concluded that the statute was not unconstitutionally vague, because it did no more than direct doctors to act responsibly, while allowing them freedom to exercise the professional judgment of necessity "in the light of all factors-physical, emotional, psychological, familial, and the woman's age-relevant to the well-being of the patient." 47 This list of factors has been offered as the "Bolton definition" of "medically necessary." 48

It has been argued that Beal v. Doe implicity adopted this Bolton definition, ${ }^{49}$ apparently because the Beal Court took note of the parties' assertion that the Pennsylvania regulation was broad enough to encompass the Bolton

41. 432 U.S. at 444.

42. Id. at 446 (the Court would not "presume that Congress intended to condition a State's participation in the Medicaid program on its willingness to undercut [an] important interest ....").

43. $\dot{I d}$.

44. 42 U.S.C. $\$ 1396$ (1976).

45. 410 U.S. 179 (1973). Bolton was a companion case to Roe v. Wade, 410 U.S. 113 (1973), in which the Court held that the constitutionally protected right of privacy includes a qualified right to terminate pregnancy, and that a state may not directly interfere with the decision of a woman and her physician to exercise this right. In Bolton, the Court struck down certain procedural requirements of the Georgia abortion statute as unduly burdening the constitutional right defined in Roe v. Wade, and then held that the remainder of the statute-which prohibited abortions that were not, in the attending physician's judgment, "necessary"- was not void for vagueness.

46. 410 U.S. at 191.

47. Id. at 192 .

48. See, e.g., Smith v. Ginsberg, No. 75-0380 CH (S.D.W. Va. May 9, 1978).

49. See D.R. v. Mitchell, 456 F. Supp. 609, 621 (D. Utah 1978); Plaintiffs' Brief in Support of Interim Relief at 6-7, Right to Choose v. Byrne, No. C-3817-77 (N.J. Super. Ct. Ch. Div. Jan. 10, 1979), 
factors..$^{50}$ Of course, the issue of funding restrictions on medically necessary services was not before the Court in Beal. ${ }^{51}$ More important, the Bolton standard cannot be reconciled with the holding in Beal: the Bolton definition encompasses elective, or non-therapeutic, abortions performed for familial, social, or emotional reasons, while the Beal decision held that states may limit funding for such abortions.

Moreover, the Bolton definition is inappropriate in the funding context of Medicaid. The Court presented that definition on the same day it established that, as a constitutional matter, a state may not directly interfere with a physician's judgment that an abortion should be performed. ${ }^{52}$ The Court has since held, however, that a state has no constitutional obligation to pay for medical care, including abortions: ${ }^{53}$ a denial of Medicaid funding is thus not considered a direct interference with a physician's judgment. ${ }^{54}$ Therefore, in determining how best to allocate its Medicaid funds, a state has more freedom to implement policy choices and value judgments favoring some medical procedures over others, and may choose to limit payment to fewer situations than those encompassed within the Bolton factors. Title XIX's intense concern for cost control and proper utilization of services ${ }^{55}$ supports the conclusion that the Bolton standard, which encompasses elective or unnecessary procedures, cannot represent a minimum requirement in the funding context.

Justice Brennan's dissent in Beal suggests another definition of "medically necessary." ${ }^{56} \mathrm{He}$ contended that when a patient suffers from a condition requiring some sort of medical treatment-such as pregnancy, for example-any treatment chosen by a physician is "medically necessary." ${ }^{77}$ This definition closely parallels that of the medical community, which considers any safe and efficacious treatment responsive to a medical problem to be "necessary." 58 However, Justice Brennan's "condition" argument was implicitly rejected in Beal, since the Court in that case examined the necessity of the particular treatment at issue, rather than the need for any treatment at all. Furthermore, neither Justice Brennan's definition nor that of the medical community can be reconciled with the holding in Beal that a state is not required to fund elective procedures since, under either view, many such procedures could be considered "necessary." More important, such broad definitions are clearly incompatible with a state's statutory authority

50. After setting forth the Bolton standards, the Court stated: "We were informed during oral argument that the Pennsylvania definition of medical necessity is broad enough to encompass the factors specified in Bolton." 432 U.S. at 442 n.3.

51. The regulation at issue in Beal only restricted funding for non-necessary abortions. See note 37 and accompanying text supra.

52. See note 45 supra.

53. Maher v. Roe, 432 U.S. 464, 469 (1977) (laws restricting Medicaid benefits for elective abortions do not violate the equal protection clause).

54. Id. at 473-75.

55. See notes 24-35 and accompanying text supra.

56. 432 U.S. at 448 (Brennan, J., dissenting).

57. Id. at 450 .

58. For a thorough discussion of the attempts to define "medically necessary," see Butler, The Right to Medicaid Payment for Abortion, 28 Hastings L. J. 931, 954-58 (1977). 
to establish standards for the scope and duration of covered services, ${ }^{59}$ and are inconsistent with Congress's desire to control Medicaid's escalating costs. $^{60}$ Thus, these definitions of "medically necessary" must also be rejected.

One court has adopted an extremely narrow definition of "medically necessary," uniquely tailored to abortions. In D.R. $v$. Mitchell, ${ }^{61}$ the District Court for Utah apparently assumed that all "medically necessary" abortions must be funded under Medicaid. In defining this class of abortions, however, the court gave great weight to the fact that, at the time title XIX was enacted, abortions were generally illegal unless necessary to preserve a woman's life. Consequently, the court defined "medically necessary" abortions to include only such life-saving procedures. ${ }^{62}$ This reasoning ignores the fact that title XIX is framed in terms of general categories of care rather than specific procedures. ${ }^{63}$ Thus, the Mitchell standard, or any other definition tailored to a specific procedure, cannot be a valid tool for analyzing state restrictions on Medicaid funding.

2. A Proposed Definition. To be suitable in the funding context, the definition of "medically necessary" must not be so broad that it clearly contradicts statutory concerns. At the same time, it must not be drawn so narrowly that it only applies to one particular procedure. In light of these considerations, the most appropriate definition of "medically necessary" care is: any item or procedure indicated to prevent or cure a condition that poses serious danger to the physical or mental health of an individual. ${ }^{64}$ This definition excludes purely elective procedures, and it provides guidance to both states and physicians to determine whether services and facilities are utilized only so far as necessary. Since it establishes a range of nonnecessary, or elective, services that a state may restrict, the definition is compatible with the congressional desire to reduce the costs of the Medicaid program.

\section{B. Does Title XIX Require States to Fund All Medically Necessary Services?}

Although the definition of "medically necessary" presented above is not so obviously inconsistent with title XIX as are the other formulations that

59. See notes 18-21 and accompanying text supra.

60. See notes 24-35 and accompanying text supra.

61. 456 F. Supp. 609 (D. Utah 1978).

62. Id. at 623. But see Zbaraz v. Quern, [1978 Transfer Binder] Medicare \& MEdiCaID GuIDE (CCH) \29,001, at 9730 (N.D. Ill. May 15, 1978): "[n]ecessary medical services are more than services to save a life in peril."

63. See notes 149-51 and accompanying text infra.

64. This definition should be construed to include follow-up and pretreatment care, as well as treatment necessary to prevent serious deformity or malfunction.

Of course, the final judgment of medical necessity must be left to the medical profession. Any definition that might be formulated is therefore susceptible to the problems of abuse and varying individual interpretations that work to broaden coverage. There is no alternative to reliance on professional judgment, however, because the endless variety of individual situations that may make a procedure medically necessary could never even be catalogued, much less codified. 
have been advanced, the question remains whether states must fund all services falling within this definition. Some courts relied on Beal v. Doe in holding that states must fund all medically necessary care. ${ }^{65}$ Beal, however, did no more than approve a restriction on benefits for elective abortionsit cannot be read as thereby disapproving limitations on funding for necessary abortions. Rather than settling the latter question, the Court carefully left it open, indicating that "serious statutory questions might be presented if a state Medicaid plan excluded necessary medical treatment from its coverage ...." 66 The answer to these "serious questions" lies in careful examination of the statute.

The principal statutory basis for the contention that states cannot eliminate coverage for medically necessary services is the general purpose clause, section 1396, and its undefined reference to "necessary medical services." This phrase is explicitly used to describe the beneficiaries of the program: "individuals whose income and resources are insufficient to meet the costs of necessary medical services." ${ }^{67}$ The phrase can also be read to implicity modify "medical assistance" ${ }^{8}$ - the assistance provided under a program designed to aid those who cannot afford "necessary medical services" should at least cover such services. ${ }^{69}$ Even if it is inferred that "necessary" does modify "medical assistance," however, any obligation to provide "necessary medical assistance" is expressly limited by yet another clause of section 1396 -assistance need only be furnished "as far as practicable under the conditions in [each] state." Thus, while section 1396 establishes that one of Medicaid's objectives is to provide necessary medical services, it also reflects a congressional intent that each state have the freedom to tailor programs that are responsive to the fiscal conditions prevalent in that state. Other objectives of the Medicaid program are to encourage states to provide high quality medical care to indigents at the lowest possible cost, and to discourage costly and wasteful misutilization of services. ${ }^{70}$ If a state is required

65. See, e.g., Rush v. Parham, 440 F. Supp. 383, 389 (N.D. Ga. 1977), appeal filed sub nom. Rush v. Poythress, No. 77-2743 (5th Cir. Apr. 1978): "we believe that Beal v. Doe... also identifies the services within the five broad categories which are required to be covered by a State Medicaid Plan and those are the services which are deemed 'medically necessary." See also Smith v. Ginsberg, No. 75-0380 CH (S.D.W. Va. May 9, 1978).

66. 432 U.S. at 444 (emphasis added).

67. The First Circuit relied on the context of the phrase-in the authorization section, describing the intended beneficiaries of the program-in concluding that "necessary medical services" does not impose a substantive funding requirement. Preterm, Inc. v. Dukakis, No. 78-1324, slip op. at 6 (1st Cir. Jan. 15, 1979).

68. See notes 16-17 and accompanying text supra.

69. Judge Mulligan, dissenting in Roe v. Norton, 522 F.2d 928, 939-40 (2d Cir. 1975), argued that "necessary" implicity modified "medical assistance," so that states were prohibited from funding unnecessary, or elective, services. This view is inconsistent with Congress's original intention that Medicaid recipients should receive comprehensive coverage of all services ordered by a physician. See notes 27-28 and accompanying text supra.

Beal v. Doe squarely rejects Judge Mulligan's view, holding that "the federal statute leaves a State free to provide such coverage [for elective procedures] if it so desires." 432 U.S. at 447.

70. These additional objectives can be gleaned from the $1965 \mathrm{~S}$. REP., supra note 2, and the reports accompanying amendments to title XIX. See, e.g., S. REP. No. 222, supra note 8 H. R. REP. No. 231, supra note 8 . 
to fund all medically necessary services, other viable objectives-especially those of cost control and state discretion to meet fiscal concerns-will be undercut. Therefore, it is unlikely that Congress intended that a requirement be inferred from section 1396, since such a construction would be detrimental to other statutory concerns.

Moreover, in the context of Social Security Act grant programs, broadly stated goals are rarely equivalent to requirements imposed on the states. ${ }^{\mathbf{7 1}}$ The Supreme Court recently reemphasized this principle in Quern v. Mandley, ${ }^{72}$ a case which raised issues of state discretion versus federal mandate in the Aid to Families with Dependent Children program, title IV-A of the Social Security Act. ${ }^{73}$ The Court noted that the potential breadth of Social Security programs, as stated in general purpose clauses, militates against drawing the inference that Congress intended to require states to extend aid as far as suggested by these clauses. ${ }^{74}$ To support this conclusion the Court examined the general purpose clause of title $\mathrm{XX},{ }^{75}$ which like the Medicaid statute's general purpose clause, directs states to provide assistance only "as far as practicable under the conditions in that state." The Court concluded that such language vests ultimate decisionmaking authority in the states. ${ }^{76}$ Absent express language to the contrary, therefore, general purpose clauses merely define the parameters of a program for which federal funding will be available, rather than imposing mandatory funding requirements on the states.

Under the analysis of Quern v. Mandley, section 1396 alone is hardly sufficient to support a conclusion that states must fund all medically necessary services. Other provisions of the Medicaid statute must therefore be examined to determine whether there is any express support for such a requirement in title XIX.

One statutory section offered as evidence that states are expressly re-

71. Such grant programs customarily leave administration and program details to the states. Those requirements that are imposed are set forth in a separate statutory section detailing the necessary components of a state program plan, see, e.g., 42 U.S.C.A. $\S$ 1396a(a) (1)-(40) (West 1974 \& Supp. 1978), rather than in the clauses authorizing appropriations for general purposes. Requirements are usually included to ensure that federal funds will be spent in an efficient, honest manner, consistent with congressional aims. $C f$. Oklahoma v. United States Civil Serv. Comm'n, 330 U.S. 127, 142-43 (1947) (federal government has power to fix terms on which funds allotted to states may be disbursed, to assure that funds are spent in accordance with federal policy).

72. 436 U.S. 725, 745 (1978).

73. Illinois's Emergency Assistance (EA) program for needy families was challenged because it limited eligibility for assistance more narrowly than did the federal standard in 42 U.S.C. $\$ 606(e)$ (1976). The Court concluded that $\$ 606$ defines the permissible scope of an EA program for purposes of federal funding, but does not impose mandatory eligibility standards on participating states, because states have broad discretion to shape their programs under the Social Security Act, as evidenced by language in general purpose clauses. 436 U.S. at 745 .

74. The Court pointed out that a literal application of such broad goals "would create an entirely open-ended program, not susceptible of meaningful fiscal or programmatic control by the States." Id. at 746.

75. 42 U.S.C. $\$ 1397$ (1976), which provides for appropriations to "encourag[e] each State, as far as practicable under the conditions in that State, to furnish services directed at the goal of . . . achieving or maintaining economic self-support to prevent, reduce, or eliminate dependency ..." (emphasis added).

76. 436 U.S. at 745 (quoting 42 U.S.C. $\$ 1397$ (1976)). 
quired to fund all medically necessary services is section $1396 \mathrm{a}(\mathrm{a})(19)$, which directs state plans to "provide . . . safeguards ... to assure that ... care and services will be provided in a manner consistent with simplicity of administration and the best interests of the recipients." 77 It has been argued that limitations excluding necessary services are never in the best interests of recipients, and thus violate the statute. ${ }^{78}$ The Senate report accompanying the Medicaid bill, however, reveals that the principal purpose of this provision is to facilitate indigents' access to medical care by minimizing complicated administrative procedures that would delay eligibility decisions and discourage health-care providers from participating in the program. ${ }^{79}$ The legislative history lacks an indication that the "best interests" clause is aimed at the services that a state must cover. Thus, section 1396a (a) (19) is hardly evidence of a specific intent to require states to fund all medically necessary services.

The HEW regulation approving coverage limits based on the criterion of medical necessity ${ }^{80}$ provides a second possible indication that the Medicaid scheme prohibits states from restricting funding for medically necessary services. It has been argued that this regulation should be read as allowing limits only on nonnecessary services. On its face, however, the regulation does no more than suggest that a restriction on funding unnecessary services is one of a number of limits that would satisfy the statutory standard of reasonableness. The regulation is addressed solely to the question of what states do not have to fund-it cannot be read to impose an affirmative obligation to fund all services except those within the suggested limitation. ${ }^{81}$

In addition to suggesting limits on unnecessary services, this regulation expressly permits states to limit the duration of covered services. ${ }^{82}$ As applied to some services-such as the number of inpatient days or physician visits that will be funded - this regulation would authorize exclusion of Medicaid benefits for some medically necessary services, since there will always be individuals needing these services beyond the number of days covered under a state plan. ${ }^{83}$ Therefore, far from indicating that states may not restrict funding for medically necessary services, this regulation actually permits states to limit funding of some medically necessary care.

The preceding analysis demonstrates that under title XIX, the goal of providing all necessary care cannot be read as an irreducible minimum re-

77. 42 U.S.C. $\S 1396 a$ (a) (19) (1976).

78. See notes $22-23$ and accompanying text supra.

79. 1965 S. Rep., supra note 2, at 76, reprinted in [1965] U.S. Code Cong. \& AD. News at 2017: "This provision was included in order to provide some assurance that the States will not use unduly complicated methods of determining eligibility ... or . . . administer the provisions for services in a way which adversely affects the availability or the quality of the care to be provided."

80. 42 C.F.R. $\$ 449.10$ (a) (5) (i) (1977).

81. Congress's desire to discourage costly misutilization of services, see notes 25-26 and accompanying text supra, supports the conclusion that this regulation speaks only to the question of permissible coverage limitations rather than coverage requirements. 1977).

82. See note 21 and accompanying text supra.

83. See, e.g., Virginia Hosp. Ass'n v. Kenley, 427 F. Supp. 781, 785 (E.D. Va. 
quirement on the states. Several important amendments to title XIX support this conclusion. The comprehensive coverage clause, section $1903(\mathrm{e}),{ }^{84}$ would have at least required that states fund all necessary medical services, and probably would have compelled coverage of a full range of elective or non-necessary care as well. ${ }^{85}$ Fiscal pressures forced Congress to abandon the comprehensive coverage requirement in $1972,{ }^{86}$ precisely because it was no longer feasible to require states to provide such coverage. ${ }^{87}$ When section 1903(e) was repealed, the only textual support for the conclusion that the funding of all necessary medical services is a requirement rather than a goal also disappeared.

The 1972 amendment that repealed section $1902(d){ }^{88}$ also indicates that states are not required to fund all medically necessary services. This amendment gave states much greater freedom to eliminate optional service categories from their plans and reduce the scope of coverage within mandatory categories. ${ }^{89}$ Some optional services may, in many instances, be medically necessary. Prescription drugs are an obvious example. ${ }^{90}$ Since states are expressly permitted to eliminate such items from their plans, it cannot be concluded that they must fund all medically necessary services.

The evolution of the Medicaid statute reveals a conflict between Congress's initial intent to mandate comprehensive coverage and Congress's second thoughts about the program. But it is these second thoughts, motivated by fiscal concerns, that shape the Medicaid program as it exists today. The trend has been toward limiting both the scope and the cost of Medicaid. A "medical necessity" coverage requirement would be contrary to both trends. Since there is neither any express indication that it be a requirement, nor even a definition of the term in the statute, the phrase "necessary medical services" cannot be viewed as a coverage mandate upon the states.

While it does not represent a minimum funding requirement on the states, the concept of medical necessity is still highly relevant in evaluating state restrictions on Medicaid coverage. The statutory scheme requires that state coverage standards be reasonable. As later discussion will demonstrate, the reasonableness of any given restriction will often turn on the extent to which the medical needs of the Medicaid population still are met.

\section{Specific Limitations-What is Reasonable?}

Although title XIX does not require participating states to fund all medically necessary services, state restrictions on the funding of such services

84. Social Security Amendments of 1965 Pub. L. No. 89-97, $§ 1903($ e), 79 Stat. 286 (originally codified at 42 U.S.C. $\$ 1396 \mathrm{~b}(\mathrm{e})(1970)$ ). For text of this clause, see note 27 supra. 85. See note 28 and accompanying text supra.

86. See notes 29-31 and accompanying text supra.

87. S. REP. No. 91-222, supra note 8, at 5-6, reprinted in [1969] U.S. Code CoNG. \& AD. News at 1081.

88. See notes $32-35$ and accompanying text supra.

89. See note 35 and accompanying text supra.

90. See Dodson v. Parham, 427 F. Supp. 97 (N.D. Ga. 1977); notes 131-40 and accompanying text infra. 
must still be "reasonable" ${ }^{21}$ in the context of the Medicaid scheme. Since Medicaid is a program of "cooperative federalism," 92 the reasonableness of a given restriction depends in large part upon the state interest that underlies it.93

The most commonly advanced state interest justifying coverage restrictions is the need for fiscal control of the state program.94 Since title XIXparticularly as amended ${ }^{95}$-recognizes the importance of the state's fiscal interests, coverage limitations that greatly reduce costs should carry a strong presumption of reasonableness..$^{96}$ Of course, every restriction of a state plan's coverage results in some immediate cost savings. When a restriction yields little $e^{97}$ or $\mathrm{no}^{98}$ cost savings over the long run, however, the state's fiscal interest in imposing such a limitation deserves little weight.

When a state coverage restriction is challenged, the Medicaid scheme requires that the state's fiscal concerns be balanced against the statutory interest in providing for the health care needs of the indigent. ${ }^{99}$ This Note will next examine various restrictions that states have imposed on the coverage of their Medicaid plans, and apply this balancing test to determine their validity.

91. See notes 19-20 and accompanying text supra.

92. See notes $2-7$ and accompanying text supra.

93. See Beal v. Doe, 432 U.S. 438, 446 (1977) (Congress did not intend that a state be required to undercut its "unquestionably strong and legitimate interest in encouraging normal childbirth" as a condition of participating in Medicaid).

94. The state interest in fiscal control has two distinct elements: first, the interest in reducing costs and limiting the growth of the welfare budget; and second, the interest in retaining control over the allocation of welfare funds among competing uses. The Medicaid scheme, however, accords less weight to the latter interest. See note 96 infra.

95. Most notably, $\S 1903$ (e), the comprehensive coverage requirement, was repealed to alleviate the fiscal burden on the states. See notes 27-31 and accompanying text supra. Other amendments to title XIX were also motivated by the problem of excessive costs. See notes 32-35 and accompanying text supra.

96. Title XIX gives greater weight to the state's interest in saving money than to the state's interest in retaining control over the allocation of its welfare resources. The former interest is reflected in several ways: medical assistance must be provided only to the extent financially practicable for a state, 42 U.S.C. $\$ 1396$ (1976); provision is made for ratesetting and utilization review requirements designed to control costs, id. § 1396a(a)(30)-(33) (1976) as amended by Medicare-Medicaid Anti-Fraud and Abuse Amendments, Pub. L. No. 95-42, §2(a)(3), 91 Stat. 1176 (1977); and the statute has been amended several times in order to reduce the demand on state finances, see notes 27-35 and accompanying text supra.

On the other hand, by participating in the program-and thus accepting the federal requirements that it imposes-states necessarily relinquish some authority over the allocation of welfare resources.

97. For example, the cutbacks in coverage of prescription drugs struck down in Dodson v. Parham, 427 F. Supp. 97 (N.D. Ga. 1977), eliminated the provision of many inexpensive drugs, which compelled doctors to issue multiple prescriptions for the individual elements of the compounds, at a substantially higher cost. See notes 131-40 and accompanying text infra.

98. Abortion funding restrictions do not produce net cost-savings because the alternative, childbirth, is more expensive. See notes 156-57 and accompanying text infra.

99. The interest in protecting health underlies the entire Medicaid program, see notes 2-3 and accompanying text supra, and is reflected in the statutory sections discussed in notes 13-35 and accompanying text supra.

Although the amendments to title XIX were motivated by fiscal concerns, Congress viewed these modifications as consistent with, rather than in derogation of, the health interest; by allowing states to trim their Medicaid programs, Congress clearly intended that "[state fiscal] crises should not operate to prevent the poor from receiving basic medical care and services ...." H.R. REP. No. 231, supra note 8, at 12, reprinted in [1972] U.S. Code Cong. \& AD. News at 5086. 


\section{A. Durational Limits and the Statistical Impact Test}

States are expressly authorized to place durational limits on covered services, ${ }^{100}$ and this restrictive technique has proved popular. ${ }^{101}$ Virginia, for example, limits reimbursement for hospital stays to the first twenty-one days of hospitalization. This provision was upheld by a lower federal court in Virginia Hospital Association v. Kenley, ${ }^{102}$ even though as a matter of medical necessity some Medicaid recipients would require more than twentyone days of hospitalization. ${ }^{103}$ The court examined the Virginia limitation in light of the HEW regulation that requires items of medical care covered by a state plan to be "sufficient in amount, duration and scope to reasonably achieve their purpose." 104 Construing this regulation to mean that service coverage need not meet every individual's needs, but must only be sufficient to meet the needs of the Medicaid population as a whole, ${ }^{105}$ the court adopted a statistical impact test to determine the sufficiency of Virginia's hospitalization coverage. The hospital stays of ninety-two percent of Medicaid recipients needing hospitalization fell within the twenty-one day limitation, and thus were funded in their entirety. ${ }^{106}$ The court therefore concluded that Virginia's coverage of hospital care was entirely reasonable, and the twenty-one day limitation valid. ${ }^{107}$

The premise underlying the Virginia Hospital Association decisionthat a coverage limitation is reasonable if the needs of most Medicaid recipients are met-necessarily follows from the statutory provision allowing states to formulate standards governing the extent of medical assistance that will be covered. ${ }^{108}$ If the purpose of an item of medical care had to be "reasonably achieved" for each patient, then no general limits could be imposed on the scope, duration, or amount of covered services, and a state's authority to establish coverage standards would be meaningless. Such a result is clearly untenable, particularly in light of the statute's legislative history. ${ }^{109}$ And since sufficiency of service coverage must be analyzed for the

100. 42 C.F.R. $\S 449.10$ (a)(5)(i) (1977).

101. Eighteen states have placed durational limits on inpatient services, physicians' services, nursing home services, and other types of care. See [1977] 2 MediCARE \& MedicaID GuIDE (CCH) Iq 15,500-15,660.

102. 427 F. Supp. 781 (E.D. Va. 1977).

103. The court rejected the contention that title XIX requires funding of all medically necessary services as incompatible with the express authority to impose durational limits. Id. at 785 .

104. 42 C.F.R. $\S 449.10$ (a) (5) (i) (1977).

105. 427 F. Supp. at 785-86.

The court's interpretation is in accord with that of $\mathrm{HEW}$, see id., and is consistent with title XIX, see notes 108-09 and accompanying text infra.

106. 427 F. Supp. at 786.

107. The court also argued that the limit was justified because it was rationally related to the state's legitimate interest in controlling the costs of its Medicaid program. Id. at 784. Of course, any durational limitation will result in cost-savings; to be valid, however, such a limitation must also meet the requirement of reasonableness that is reflected in the statistical impact test.

108. 42 U.S.C. $\$ 1396 a(a)(17)$ (1976).

109. Congress clearly indicated that the phrase "extent of medical assistance under the plan," 42 U.S.C. $\$ 1396 a(a)(17)$ (1976) (emphasis added), means that states may determine "the number of days of care provided under the plan." 1965 S. REP., supra note 2, at 81. 
Medicaid population as a whole, the statistical impact test employed in Virginia Hospital Association is a sound approach for analyzing the validity of other types of durational limitations.

The New Jersey plan contains a durational limitation on hospitalization coverage $^{110}$ that differs substantially from Virginia's absolute twenty-one day limitation. Rather than restrict coverage to an arbitrary number of days, New Jersey extends Medicaid benefits for each patient only for the period during which that patient requires acute-level hospital care. Coverage terminates when a patient may be satisfactorily treated in a skilled nursing facility. The state suffers from a shortage of nursing home beds available for Medicaid recipients, however, and many patients must therefore remain hospitalized while awaiting more appropriate placement. ${ }^{111}$ Although these patients no longer need hospital care, they still need some level of inpatient care:112 the prolonged hospital stays are medically necessary, but are not fully covered by New Jersey's Medicaid plan.

This limitation was challenged in Monmouth Medical Center v. New Jersey. ${ }^{113}$ The court assumed that title XIX required reimbursement of all medically necessary inpatient services, ${ }^{114}$ and thus held that New Jersey's limitation was invalid because it excluded benefits for patients who still needed some level of inpatient care. Under the court's analysis, the con-

See also id. at 79; 42 U.S.C. $\$ 1396 a(a)(13)(D)$ (1976) (a state must provide "for payment of the reasonable cost of inpatient hospital services provided under the plan") (emphasis added).

The fact that a state may choose to cover only part of the cost of any service, 42 U.S.C. $\$ 1396 \mathrm{~d}$ (a) (1976), also supports the conclusion that title XIX does not require that the full purpose of an item of medical care be achieved for every individual.

110. Sections 202 and 202.9 of the New Jersey Hospital Service Manual, derived from N.J. Admin. Code 10:52-1.2(a)-(b)(1), provide that:

202. Benefits are not payable for any services rendered or items dispensed or furnished in connection with:

202.9 Inpatient hospital services rendered after the day it is medically necessary, except when special circumstances prevent the discharge or transfer of the patient....

Payment for special circumstances (social necessity) is specifically precluded for:

(a) Patients awaiting placement in a skilled Nursing Facility or Intermediate Care Facility.

These sections are reproduced in Monmouth Medical Center v. New Jersey, 158 N.J. Super. 241, 248 (App. Div.), certification granted, 77 N. J. 506 (1978).

111. See, e.g., Brief and Appendix for Respondents at 2, 10, Monmouth Medical Center v. New Jersey, 158 N. J. Super. 241 (App. Div.), certification granted, 77 N. J. 506 (1978).

112. The New Jersey limitation is tied to individual need, but not to the full extent of medical necessity. It may thus be contrasted with the New York rule that ostensibly limits funding for pre-operative inpatient care to one day, N.Y. Soc. SERv. LAw $\S 365-\mathrm{a}(5)$ (d) (McKinney Supp. 1978), but that has been interpreted to allow coverage for as many days as are required for a particular patient. 10 N.Y. CodB RULES \& REGS. $\S 85.4(\mathrm{a})$. The New York limitation as applied-upheld in Medical Soc'y v. Toia, [1977-1978 Transfer Binder] MediCARB \& MediCAID GuIDB (CCH) I 28,364 (E.D.N.Y.), rev'd on other grounds, 560 F.2d 535 (2d Cir. 1977)-thus turns on individual need, to the full extent of medical necessity.

113. 158 N. J. Super. 241 (App. Div.), certification granted, 77 N. J. 506 (1978).

114. The court based this assumption on its conclusion that "the primary object of [the Medicaid] program is adequate patient care which is found to be medically necessary." Id. at 252. 
trolling factor for determining medical necessity was not where care is performed, but whether any inpatient care is required.

Because the court assumed that title XIX requires states to fund all medically necessary services, it discounted the strong state interests that made the New Jersey limitation both reasonable and consistent with the objectives of title XIX. New Jersey's refusal to fund hospital stays after the point at which a patient can be treated more properly in a skilled nursing facility is intended to discourage overutilization of inpatient services by encouraging hospitals to locate nursing home beds as soon as possible. ${ }^{115}$ This purpose is entirely consistent with the objectives and requirements of title XIX since the statute explicitly requires states to provide safeguards against overutilization. ${ }^{116}$

New Jersey also has strong fiscal interests in imposing such a limitation. The state has estimated that absent the limitation, an additional annual expenditure of $\$ 37.7$ million would be required to fund prolonged hospital stays. ${ }^{117}$ Permitting the limitation also serves New Jersey's interest in controlling the allocation of state welfare resources. ${ }^{118}$ Forcing the state to bear the additional expense of prolonged hospital stays could lead to cuts in other areas-such as reductions in coverage of optional services-that would be detrimental to the state's entire Medicaid population. But the state has made a permissible policy choice to use its welfare budget to cover optional categories rather than the entire duration of all hospital stays. These state fiscal concerns provide strong support for the argument that New Jersey's limitation is reasonable.

\section{B. Cutbacks on the Scope of Services Within Mandatory and Optional Service Categories}

In addition to limiting the duration of covered services, states have responded to fiscal concerns by reducing the scope of services offered within specific statutory coverage categories. For example, New York limits benefits for surgery to emergency situations, to those procedures necessary to alleviate severe pain or threats of disability and death, and to operations that cannot be deferred without substantially increasing the medical risk in-

115. Id. at 251 .

116. 42 U.S.C. $\S 1396 a(a)(30)$ (1976) requires state plans to "provide such methods and procedures relating to the utilization of . . . care and services available under the plan . . as may be necessary to safeguard against unnecessary utilization of such care and services ...."See notes 24-26 and accompanying text supra.

117. Affidavit of Ann Klein, Respondent's Petition for Certification to the New Jersey Supreme Court at 20a, Monmouth Medical Center v. New Jersey, 77 N.J. 506 (1978).

118. See notes $94-96$ and accompanying text supra. 
volved. ${ }^{119}$ In Medical Society v. Toia, ${ }^{120}$ the United States Court of Appeals for the Second Circuit upheld this limitation as consistent with the state's statutory obligation to safeguard against unnecessary utilization of medical services. ${ }^{121}$ The court also relied on the HEW regulation which expressly provides that appropriate "limits may be placed on services based on such criteria as medical necessity" ${ }^{122}$ without discussing the definition of "medical necessity."

In limiting medical assistance for surgery to the specified situations, New York was responding to the HEW regulation authorizing limitations on unnecessary procedures. Although the district court concluded that New York's definition of "medically necessary" was too narrow, ${ }^{123}$ such a narrow definition is appropriate in the funding context. New York's statute does provide benefits when a serious health threat exists, and the limitation is therefore compatible with the title XIX health interest. ${ }^{124}$ Moreover, the statute was enacted in response to an identified problem of overutilization of surgical services by Medicaid recipients, ${ }^{125}$ and is thus consistent with title XIX's requirement that states discourage misutilization of services. ${ }^{126}$

Finally, the limitation is consistent with title XIX's cost-control objective, in light of the state fiscal interests involved. New York was concerned by the high rate of unnecessary surgery that contributed to the burdensome cost of its Medicaid program; ${ }^{127}$ by eliminating such surgery, the state could

119. N. Y. Soc. SeRv. LAW $\$ 365-a(5)$ (McKinney Supp. 1978) provides in part: (a) Medical assistance shall include surgical benefits for emergency or urgent surgery for the alleviation of severe pain, for immediate diagnosis or treatment of conditions which threaten disability or death if not promptly diagnosed or treated. (b) Medical assistance shall include surgical benefits for surgical procedures which meet standards for surgical intervention, as established by the state commissioner of health on the basis of medically indicated risk factors, and medically necessary surgery where delay in surgical intervention would substantially increase the medical risk. ... .

(c) Medical assistance shall include surgical benefits for other deferrable surgical procedures specified by the state commissioner of health, based on the likelihood that deferral of such procedures for six months or more may jeopardize life or essential function, or cause severe pain ....

120. 560 F.2d 535 (2d Cir. 1977), rev'g [1977-1978 Transfer Binder] Medicare \& MedicAID GUIDE (CCH) 28,364 (E.D.N.Y. 1977). The district court had adopted a broad definition of medically necessary care, regarding it as any usual therapeutic treatment for a condition. The New York restriction was thus considered faulty because many procedures that were medically indicated under the court's definition would not be funded. The district court held, in the alternative, that every procedure falling within the mandatory coverage category of physician's services had to be funded by the state. This opinion, issued before the Supreme Court decided Beal v. Doe, is clearly no longer valid in light of Beal's holding that states do not have to fund every procedure within the mandatory service categories.

121. See notes 24-26 and accompanying text supra.

122. 42 C.F.R. $\S 449.10$ (a)(5)(i) (1977).

123. The district court broadly defined "medically necessary" as any therapeutic treatment ordered by a physician to respond to a condition causing inconvenience or discomfort. [1977-1978 Transfer Binder] Medicare \& Medicald GuidB (CCH) 9 28,364, at 9285. This standard of broad deference to the physician's judgment is inappropriate in the funding context. See notes 56-60 and accompanying text supra.

124. See note 99 and accompanying text supra.

125. 560 F.2d at 537 .

126. See notes $24-26$ and accompanying text supra.

127. See 560 F.2d at 537 . 
save up to sixty-five million dollars annually. ${ }^{128}$ The magnitude of this fiscal interest creates a presumption that the restriction is reasonable. ${ }^{128}$ Moreover, when this strong state fiscal interest is considered in light of the restriction's accommodation of the statutory health interest, New York's limitation on surgical benefits satisfies the reasonableness test.

New York's limitation affected the scope of services within a mandatory coverage category. More typically, however, states attempt to limit the scope of optional service categories. The analysis to be applied is nonetheless the same: once a state chooses to extend Medicaid benefits to optional service categories, any restrictions on care falling within these service categories must satisfy the reasonableness test. ${ }^{130}$

Georgia's Medicaid plan included benefits for the optional service category of prescription drugs. After problems with abuse of the drug program arose, the state proposed a drastic curtailment of the list of drugs approved for Medicaid reimbursement. In Dodson v. Parham, ${ }^{131}$ a federal district court enjoined implementation of the new drug formulary because it excluded many drugs necessary to treat certain individual conditions. The court relied on the HEW regulation requiring all services provided by a state, optional or mandatory, to be "sufficient in amount, duration and scope to reasonably achieve their purpose." 132 The decision implicitly assumed that title XIX requires coverage of all medically necessary care. Finding that the purpose of prescription drugs is to cure, mitigate, or prevent disease, ${ }^{\mathbf{1 3 3}}$ the court held that any limitation excluding drugs necessary for this purpose is not reasonable.

Despite the court's erroneous assumption that title XIX requires states to fund all medically necessary care, its conclusion that Georgia's restriction was unreasonable nonetheless seems valid since the cost savings expected to arise from the limitation were not large enough to outweigh the restriction's incompatibility with health concerns.

The proposed formulary of reimbursable drugs largely ignored the title XIX health interest because the new list omitted many drugs that were the only known efficacious treatment for some illnesses and within some specialized practice areas. Moreover, the list included several drugs no longer prescribed because they were outmoded or produced hazardous side effects, while excluding safer or more effective alternatives. ${ }^{134}$ Because the list excluded the only available drugs for some illnesses, it was effectively an abso-

128. Id.

129. See note 96 and accompanying text supra.

130. The statutory requirement that all standards must be reasonable extends to all categories of medical assistance offered under a state plan. 42 U.S.C. $\$ 1396 \mathrm{a}(\mathrm{a})(17)$ (1976) (the key phrase is "medical assistance under the plan").

131. 427 F. Supp. 97 (N.D. Ga. 1977).

132. 42 C.F.R. $\$ 449.10$ (a) (5)(i) (1977).

133. The court relied on the HEW regulation defining prescription drugs, 42 C.F.R. $\S 449.10$ (b) (12) (i) (1977). 427 F. Supp. at 104.

134. For the medical evidence as to the shortcomings of the new drug list, see 427 F. Supp. at 105-07. 
lute denial ${ }^{135}$ of prescription drug services in those instances. Thus, in operation the list was very close to a prohibited discrimination based solely on the diagnosis, type of illness, or condition. ${ }^{136}$

Georgia claimed that the limitation would produce an annual savings of six million dollars. ${ }^{137}$ There was medical evidence, however, that the restriction actually would result in little or no savings, because most compound drugs were not on the list. Since many of the less expensive compounds were excluded, patients would often have to purchase all the component drugs separately, at a greater cost to both the state and the individual. ${ }^{138}$

After balancing the health and fiscal interests, Georgia's restriction would appear to be unreasonable because the state's fiscal interest is not strong enough to outweigh the detriment to health. ${ }^{139}$ The restriction also would not appear to satisfy a statistical impact test of reasonableness, because there was evidence that the new list would fail to meet the needs of up to ninety percent of the Medicaid population. ${ }^{140}$

\section{Absolute Restrictions on Funding Certain Procedures}

Some states have attempted to cut back the scope of their Medicaid programs by completely prohibiting benefits for certain operations. Three states-Georgia, Minnesota, and California-prohibited funding for transsexual surgery. All three of these absolute restrictions have been struck down ${ }^{141}$ primarily on the ground that, when medically necessary, this surgery must be funded.

135. See notes $141-46$ and accompanying text infra.

136. This type of arbitrary discrimination is prohibited by the same HEW regulation that requires medical care items to be sufficient to "reasonably achieve their purpose." 42 C.F.R. $\$ 449.10$ (a)(5)(i) (1977).

137. 427 F. Supp. at 101.

138. Id. at 106-07.

The state's cost-saving justification was further reduced by its prior approval system, see $i d$. at 102-04, which would probably have cost the state more to administer than an open formulary would have cost, $i d$. at 107.

139. The court suggested that the limited drug formulary would be reasonable if it were combined with an effective prior approval system that made non-list drugs avaiiable to an individual when certified by the patient's physician to be medically necessary. Id. at 108. Cf. note 119 and accompanying text supra (New York's flexible guidelines tied to an individual's need for pre-operative care). Georgia had a prior approval system, but it was faulty because it operated only during weekday business hours and thus failed to cover emergencies, 427 F. Supp. at 108 , because it left the final say to pharmacists, id., and because it was administratively cumbersome and costly, id. at 107 .

140. 427 F. Supp. at 106. The evidence presented consisted of physicians' testimony on the effect on their practice.

141. In Rush v. Parham, 440 F. Supp. 383 (N.D. Ga. 1977), appeal filed sub nom. Rush v. Poythress, No. 77-2743 (5th Cir. Apr. 1978), the court held that Georgia's restriction violated title XIX to the extent that it irrebuttably denied coverage for medically necessary services. The court indicated that if the limitation had reserved for administrators discretion to consider individual medical necessity, it would have been reasonable.

Minnesota's absolute ban on transsexual surgery was struck down in Doe v. Minnesota Dep't of Pub. Welfare, 257 N.W.2d 816 (Minn. 1977). The Minnesota Supreme Court held that since sex conversion surgery is the only known effective treatment for transsexualism, excluding benefits for it violated the HEW regulation prohibiting states from arbitrarily denying coverage solely because of the diagnosis, type of illness, or condition. 42 C.F.R. 
Although title XIX does not require states to fund all medically necessary services, absolute restrictions on selected medical procedures almost certainly must fall for failure to satisfy the reasonableness standard. When a state absolutely prohibits benefits for a particular type of care, it ignores the statutory interest in protecting the health of indigents. ${ }^{142}$ No one in medical need of the restricted procedure will be covered, and the purpose of the restricted service will not be "reasonably achieved" for any part of the Medicaid population. Thus, absolute restrictions on selected procedures within a service category will almost always be invalid.

In the case of transsexual surgery, no state has offered interests strong enough to justify an absolute ban on the procedure. In Rush v. Parham, ${ }^{143}$ Georgia claimed that its interest in protecting the health of its citizens justified restriction. Georgia argued that transsexual surgery is experimental and therefore potentially dangerous to health. ${ }^{144}$ While protection of citizens' health is a legitimate state interest, Georgia's absolute restriction, when scrutinized, was actually detrimental to this interest. Since techniques for performing transsexual surgery have advanced beyond the point of being experimental and hazardous, ${ }^{145}$ there was no real danger to Georgia's citizens. Moreover, when an operation, even an experimental one, is truly necessary to preserve or protect an individual's health, the state has no legitimate health interest in absolutely restricting coverage for that procedure since to do so is to harm health rather than protect it.

Georgia also claimed that the restriction was motivated by fiscal concerns $^{146}$ but the state failed to offer any cost-saving figures. The number of transsexual operations performed each year, however, is so minimal that their overall cost to the state could not impose a true monetary burden. Any fiscal savings would not be great enough to outweigh the restriction's unreasonable failure to accommodate statutory health interests.

\section{Abortion Funding Restrictions}

After the Beal decision, many states passed more restrictive abortion funding laws. Many of these prohibited Medicaid reimbursement except when the life of the woman would be endangered if the pregnancy were

$\$ 449.10$ (a)(5)(i) (1977). The decision implied that coverage for all medically necessary operations is mandatory, because it directed providers to evaluate each claim and to deny benefits only when the surgery was not medically necessary.

California's Medicaid plan excluded benefits for cosmetic surgery, and state Health Department regulations included transsexual surgery within this category. In G.B. v. Lackner, 80 Cal. App. 3d 64, 145 Cal. Rptr. 555 (1978), the court invalidated the restriction on the ground that sex conversion surgery is not merely cosmetic. The court held that whenever this surgery is reasonable and necessary for the treatment of illness, title XIX requires that it be funded. Id. at 76, $145 \mathrm{Cal}$. Rptr. at 561-62.

142. See note 99 and accompanying text supra.

143. 440 F. Supp. 383 (N.D. Ga. 1977), appeal filed sub nom. Ruth v. Poythress, No. 77-2743 (5th Cir. 1978).

144. See Brief for State Appellant at 28-29, Rush v. Poythress, No. 77-2743 (5th Cir., filed Apr. 1978).

145. See G.B. v. Lackner, 80 Cal. App. 3d 64, 145 Cal. Rptr. 555 (1978).

146. Brief for State Appellant at 26-27, Rush v. Poythress, No. 77-2743 (5th Cir., filed Apr. 1978). 
carried to term. Such laws are the most frequently challenged type of Medicaid limitation. ${ }^{147}$ Since they are essentially reductions in the scope of the inpatient and physician's services coverage categories, these abortion restrictions must be subjected to the same reasonableness analysis as any other Medicaid cutback. Thus, the statutory health interest must be balanced against any state interest advanced by restrictions on Medicaid coverage for abortions. As later discussion will demonstrate, the annual Hyde Amendment to the Labor-HEW appropriations acts, ${ }^{148}$ which limits federal reimbursement for Medicaid abortions, alters neither the outcome of this balancing nor the analytical approach to be taken.

Many courts have failed to recognize that abortion funding cases require the same analysis as any other Medicaid funding case. Rather than subjecting abortion funding limitations to the standard reasonableness analysis, these courts have framed the issue as whether title XIX requires states to fund any abortions at all. These courts have thus emphasized the fact that most abortions were illegal in 1965 , when the Medicaid statute was enacted. ${ }^{149}$ Under a proper analysis, on the other hand, the legal status of abortion in 1965 is irrelevant because title XIX is not addressed to any specific medical procedure-the statute is constructed around general categories of health care services. The legislative history is devoid of any indication that Congress was thinking in terms of abortions-positively or negatively-when drafting title XIX.150 Given the constantly changing state of the art, with

147. The conflicting judicial resolutions of these challenges are remarkable for their uniform reliance on Beal v. Doe. In D.R. v. Mitchell, 456 F. Supp. 609 (D. Utah 1978), the court upheld Utah's life-endangering standard on the basis of Beal. The court relied heavily on the state's interest in encouraging normal childbirth-an argument stressed in Beal-despite the fact that Utah's limitation was far more restrictive than the Pennsylvania regulation upheld by the Supreme Court. Doe v. Kenley, No. 78-218-A (E.D. Va. May 25, 1978), rev'd, 584 F.2d 1362 (4th Cir. 1978), also relied on Beal in upholding a Virginia law allowing Medicaid payment for abortion only when the woman's life was threatened by the pregnancy.

Three other federal district courts, however, have interpreted Beal to require states to fund all medically necessary abortions. In Zbaraz v. Quern, [1978 Transfer Binder] Medicare \& Medicaid GuIDE (CCH) I29,001 (N.D. Ill. 1978), and Smith v. Ginsberg, No. 75-03080CH (S.D. W.Va. May 9, 1978), the courts struck down statutes with lifeendangering standards because those statutes were not broad enough to encompass the medical necessity factors specified in Bolton. In Emma G. v. Edwards, 434 F. Supp. 1048 (E.D. La. 1977), the court approved Louisiana's stipulation that Beal required it to fund all medically necessary abortions.

These cases raise constitutional challenges to such laws in addition to statutory challenges. The equal protection arguments, however, are no more than a rehash of contentions already rejected in Maher v. Roe, 432 U.S. 464 (1977), and have yet to be given serious consideration by any court.

148. Act of Dec. 9, 1977, Pub. L. No. 95-205, § 101, 91 Stat. 1460 . See notes $158-60$ and accompanying text infra.

149. In Beal, the Supreme Court relied on the fact that non-therapeutic abortions were illegal in 1965 to reinforce its conclusion that states do not have to fund such abortions. 432 U.S. at 447.

Other cases that have relied on the legal status of abortions in 1965 include: Roe $v$. Norton, 522 F.2d 928, 935 (2d Cir. 1975); D.R. v. Mitchell, 456 F. Supp. 609, 622 (D. Utah 1978) (the court concluded that since non-therapeutic abortions were illegal in 1965 "it is utterly untenable to suggest that the Medicaid Act as originally enacted required payment for abortions").

150. See 1965 S. RaP., supra note 2. 
the development of new devices, drugs, or surgical techniques and the discovery of new diseases or their causes, Congress could not have intended to freeze medical assistance to those procedures that were known or legal in $1965 .^{151}$ Restrictions on abortion funding must therefore be examined under the same standard of reasonableness applicable in other Medicaid funding contexts.

State laws that prohibit funding for abortions except when the woman's life is endangered are not quite the same as absolute restrictions. They are similar to absolute prohibitions, however, in that they do not allow for the exercise of administrative discretion to cover medically necessary healththreatening situations. In the context of the balance between state policy interests and health interests, these laws give little weight to the health side of the scale. To determine the reasonableness of such a restriction in the context of the Medicaid scheme, however, it is also necessary to examine the possible state interests that might underlie it. The state's interest in encouraging normal childbirth-in essence, its interest in protecting normal potential life-was deemed sufficient in Beal to uphold a restriction on funding elective abortions in non-health threatening situations. ${ }^{152}$ But this interest cannot automatically justify limitations on funding medically necessary abortions, because strong health interests exist in non-elective situations that do not enter into the balancing problem for purely elective abortions. ${ }^{153}$

Clearly, the state's interest in encouraging normal childbirth is not relevant when it can be ascertained that the fetus may be born with serious deformities. In such a case, the potential life which the state seeks to protect would not be normal, and the state therefore has no interest that it can interpose against the statutory health interest.

A much closer question arises when the pregnancy greatly jeopardizes or harms the health of the woman. ${ }^{154}$ The state's interest in protecting potential normal life must be balanced with the statutory health interest, which, in this context should be viewed as an interest in protecting the normal healthy life of the woman. Where the threat to the woman's health is clear

151. See Beal v. Doe, 432 U.S. 438, 453 (1977) (Brennan, J., dissenting); Doe v. Beal, 523 F.2d 611, 622-23 (3d Cir. 1975).

152. 432 U.S. 438,446 (1977).

153. It is important to note that the problem of restrictions on non-elective abortions remains one of balancing interests. The Court of Appeals for the First Circuit took a different approach in Preterm, Inc. v. Dukakis, No. 78-1324 (1st Cir. Jan. 15, 1979). Relying upon 42 C.F.R. $\$ 440.230$ (1978) (state may not reduce scope of any service "solely because of the diagnosis, type of illness, or condition"), the court held that it was unreasonable and inconsistent with the objectives of Medicaid for a state to single out the condition of medically complicated pregnancies "and restrict treatment for that condition to life and death situations. ... [O]ne would be hard put to discern any rational social objective being thereby served." Slip op. at 10. This analysis, however, ignores the state's interest in protecting potential life-present only in the context of abortion funding-which does provide a rational basis for distinguishing pregnancy from other medical conditions. The critical question thus remains whether this state interest in potential life outweighs the statutory health interest.

154. There are many physical conditions that cause serious health threats during pregnancy-while not, in the view of most doctors, threatening life-such as phlebitis, varicose veins, cancer, diabetes, anemia, and urinary tract infections. See ACLU, THE IMPACT OF thb Hyde Amendment on Medically Necessary Abortions 25-30 (Oct. 1978). 
and certain, the statutory health interest would appear to outweigh the state's contingent interest in potential life. ${ }^{155}$ Consequently, abortion funding restrictions that allow no discretion to cover health threatening situations are not reasonable, absent overriding state fiscal concerns.

The question arises, however, whether this statutory analysis must be altered in light of the so-called Hyde Amendment, which currently restricts federal Medicaid reimbursement for abortions. This rider to the annual Labor-HEW appropriations act authorizes federal expenditures for abortions only when the pregnancy results from rape or incest, or when continuing the pregnancy would endanger the woman's life or result in severe and longlasting physical health damage. ${ }^{156}$ Several states have adopted abortion funding laws that incorporate this standard. ${ }^{157}$ While it is somewhat broader than a life-endangering standard, on its face the Hyde Amendment standard is still too restrictive to be compatible with the statutory health interest embodied in the Medical scheme-it covers neither threats to mental health nor the many various physical health threats ${ }^{158}$ that, although serious, will not produce "long-lasting damage." ${ }^{159}$ Consequently, state abortion funding laws that adopt the Hyde Amendment standard-and a fortiori state statutes employing a life-endangering standard-are unreasonable and thus invalid, unless the Hyde Amendment has substantively altered the states' obligations under title XIX.

The Court of Appeals for the First Circuit explored this latter question in Preterm, Inc. v. Dukakis. ${ }^{160}$ After examining the legislative history-

155. While the cases provide no direct guidance as to the balance to be struck, Roe v. Wade, 410 U.S. 113 (1973), is instructive on this point. In determining the extent to which states could constitutionally restrict any abortions, the Court indicated that throughout most of the term of pregnancy the interest in maternal health clearly outweighs the state's interest in protecting potential life. The interest in potential life does not become "compelling" until the final trimester of pregnancy. Id. at 163. Throughout the term of pregnancy, however, concern for the existing life of the woman outweighs concern for the contingent, potential life of the fetus, for even during the third trimester a state may not completely proscribe abortion "when it is necessary to preserve the life or health of the mother." Id. at 164.

156. The current version of the Hyde Amendment, Act of Dec. 9, 1977, Pub. L. No. $95-205, \S 101,91$ Stat. 1460 , provides:

That none of the funds provided for in this [act] shall be used to perform abortions except where the life of the mother would be endangered if the fetus were carried to term; or except for such medical procedures necessary for the victims of rape or incest, when such rape or incest has been reported promptly to a law enforcement agency or public health service; or except in those instances where severe and long-lasting physical health damage to the mother would result if the pregnancy were carried to term when so determined by two physicians.

The constitutionality of this law is currently being challenged. McRae v. Mathews, 421 F. Supp. 533 (E.D.N.Y. 1976), vacated and remanded sub nom. Califano v. McRae, 433 U.S. 916 (1977).

157. Thirteen states have adopted the Hyde Amendment funding standard. See ACLU, supra note 154, at 1-2 app.

158. See note 154 supra.

159. The First Circuit, stressing the exclusion of funding in cases where mental health is threatened, has similarly concluded that the Hyde Amendment standard is inconsistent with the objectives of title XIX. See Preterm, Inc. v. Dukakis, No. 78-1324, slip op. at 21-22 (1st Cir. Jan. 15, 1979).

160. No. 78-1324 (1st Cir. Jan. 15, 1979).

Several district courts have commented on the Amendment's impact on the requirements 
which consists solely of emotional floor debates-the court concluded that Congress intended the Amendment to be substantive legislation, even though it was part of an appropriations act. ${ }^{161}$ The abortion funding standard of the Amendment was held to be inconsistent with title XIX because, by excluding coverage of cases where mental health is threatened, it unreasonably discriminates on the basis of diagnosis or condition. ${ }^{162}$ The only way to reconcile this conflict, the court reasoned, was to treat the Hyde Amendment as an implied repealer of a state's obligation under title XIX to fund a broader range of medically necessary abortions. While recognizing that repeals by implication-particularly when achieved through appropriations acts-are strongly disfavored, ${ }^{163}$ the court found such a reading of the Amendment to be less objectionable than one that would require states to fund abortions without federal reimbursement, thereby violating the "cooperative federalism" structure of Medicaid. The court argued that a failure to treat the Hyde Amendment as a substantive alteration of the Medicaid Act would impose "massive financial burdens" on the state-burdens that would cripple "the functioning of its entire [Medicaid] plan." 164

Upon close examination, the congressional debates on the Hyde Amendment do not support the First Circuit's conclusion that all members "of Congress were acutely aware that they were engaging in substantive legislation." ${ }^{165}$ In fact, it was only opponents of the legislation who characterized it as substantive legislation. ${ }^{166}$ Supporters of the measure stressed that it was only an appropriations bill, and thus merely an exercise of Congress's power to authorize or withhold federal funds. ${ }^{167}$ The First Circuit relied upon statements such as Representative Stokes' remark that the Amendment was "tantamount to a constitutional amendment outlawing abortions for the poor" 168 to conclude that Congress intended to alter state obligations. Once again, it was opponents who suggested such an effect. ${ }^{169}$ The sponsors and suporters of the Amendment carefully pointed out that it would "simply den[y] federal funds" for abortions. ${ }^{170}$

of title XIX. Compare Zbaraz v. Quern, [1978 Tranfer Binder] Medicare \& MedicaId GuIDE (CCH) I 29,001 (N.D. Ill. 1978), and Doe v. Mathews, 420 F. Supp. 865, 869 (D.N.J. 1976) (holding that the Hyde Amendment has no impact on the state's obligations under title XIX), with McRae v. Mathews, 421 F. Supp. 533, 538 (E.D.N.Y. 1976), vacated and remanded sub nom. Califano v. McRae, 433 U.S. 916 (1977) (Hyde Amendment is calculated to stop state funding for abortions as well).

161. Slip op. at $15-19$.

162. Id. at $20-22$.

163. See, e.g., Tennessee Valley Auth. v. Hill, 437 U.S. 153, 189-91 (1978).

164. Slip op. at 19.

165. Id. at 15 .

166. See, e.g., 123 Cong. REc. S11,035 (daily ed. July 29, 1977) (remarks by Sen. Brooke); id. at S19,440 (daily ed. Dec. 7, 1977) (remarks of Sen. Magnuson).

167. See, e.g., id. at H6086-88 (daily ed. June 17, 1977) (remarks of Reps. Doran and Rudd).

168. Slip op. at 18 (quoting 123 Cong. Rec. H6085 (daily ed. June 17, 1977)).

169. Remarks similar to those of Rep. Stokes appear at 123 CoNG. Rec. H6092 (Rep. Holtzman), H6097 (Rep. Meyner) (daily ed. June 17, 1977); id. at S11,031 (Sen Packwood), S11,040 (Sen. McGovern), S11,043 (Sen. Bayh) (daily ed. June 29, 1977).

170. Id. at H6086 (daily ed. June 17, 1977) (remarks of Rep. Doran). See also id. at H10,826-30 (daily ed. Oct. 12, 1977) (remarks of Reps. Hyde and Flood). 
All that the legislative history of the Hyde Amendment demonstrates conclusively is the danger of relying solely upon floor debates to determine legislative intent. Since the Hyde Amendment debate was extremely emotional, appeals and characterizations made by its opponents are particularly unreliable indicators of intent. The most important observation that can be gleaned from the debates is that few, if any, members of Congress were thinking about the Amendment's implications for the Medicaid Act. ${ }^{171}$ In fact, there are no express statements concerning the Amendment's impacteither in imposing funding requirements or allowing funding restrictionson the states. In light of this confused and unreliable legislative history, the principle that appropriations measures are not to be read as implied repealers ${ }^{172}$ should apply with full force. Consequently, the language of the Hyde Amendment should be taken at face value-it affects no more than federal funds.

In concluding that the Hyde Amendment had substantively altered title XIX, the First Circuit relied upon the fact that a contrary result would require states to bear the full cost of some abortions, thus violating the principle of cooperative federalism. ${ }^{173}$ This argument is misconceived. Congress's purpose in establishing the cooperative federalism funding scheme was to encourage states to participate in the program by easing the fiscal burden that such participation would place upon the states. ${ }^{174}$ But even when a state bears the full cost of a medically necessary abortion, it still pays less than what would be its share of a federally reimbursed childbirth. ${ }^{175}$ Thus, the interest of cost savings-which was the original purpose of the cooperative federalism principle-is still best served when the state funds the abortion. Consequently, the substance of the cooperative federalism principle, as opposed to its form, does not support the First Circuit's reading of the Hyde Amendment.

Since the Hyde Amendment does not substantively alter a state's obligations under title XIX, the only remaining question is whether state fiscal concerns justify the restrictions embodied in either the life-endangering or Hyde Amendment standards. In fact, states do not have valid fiscal reasons for adopting such standards, because abortions are far less costly for the state than the alternative of childbirth, which involves expensive pre-natal and post-partum care in addition to the costs of delivery. ${ }^{176}$ This is true even when the state must bear the full cost of an abortion. ${ }^{177}$ Since these restric-

171. Dissenting in Preterm, Judge Bownes noted that "Congress was so emotionally enveloped in this volatile and disruptive subject that it failed to think through the implications of what it was doing." Slip op. at 31 (Bownes, J., dissenting).

172. See Tennessee Valley Auth. v. Hill, 437 U.S. 153, 189-91 (1978).

173. See Preterm, Inc. v. Dukakis, No. 78-1324, slip. op. at 22-23 (1st Cir. Jan. 15, 1979).

174. See 1965 S. REP., supra note 2, at 73-74.

175. See note 177 and accompanying text infra.

176. See Maher v. Roe, 432 U.S. 464, 478-79 (1977).

177. New Jersey, for example, has estimated that enforcement of its restrictive abortion funding law has cost the state $\$ 3.5$ million in increased costs for childbirth and welfare support. Winer \& Haines, Courts Clash over Abortion Rider, Nat'l L. J., Feb. 5, 1979, at 5, col. 1. 
tive standards cannot be justified on fiscal grounds, the statutory health interest should therefore prevail. Consequently, both state restrictions that limit funding to those abortions required to save the woman's life, and those that adopt the Hyde Amendment standard, are unreasonable and thus invalid under the Medicaid Act.

\section{CONCLUSION}

Because the Medicaid program is an exercise in cooperative federalism, participating states retain broad discretion to shape and alter their coverage plans, subject only to vague federal requirements of reasonableness. Title XIX contains no express indication that states must fund all medically necessary services. Instead, the statute requires only that limitations on funding for such services be reasonable. Since it supplies no general formula for evaluating reasonableness, the validity of state funding restrictions can only be ascertained on a case-by-case basis. The determination must rest on a careful balancing of the statutory interest in protecting health and the state's interests-usually fiscal-in imposing the limitation.

Lucinda M. Finley 